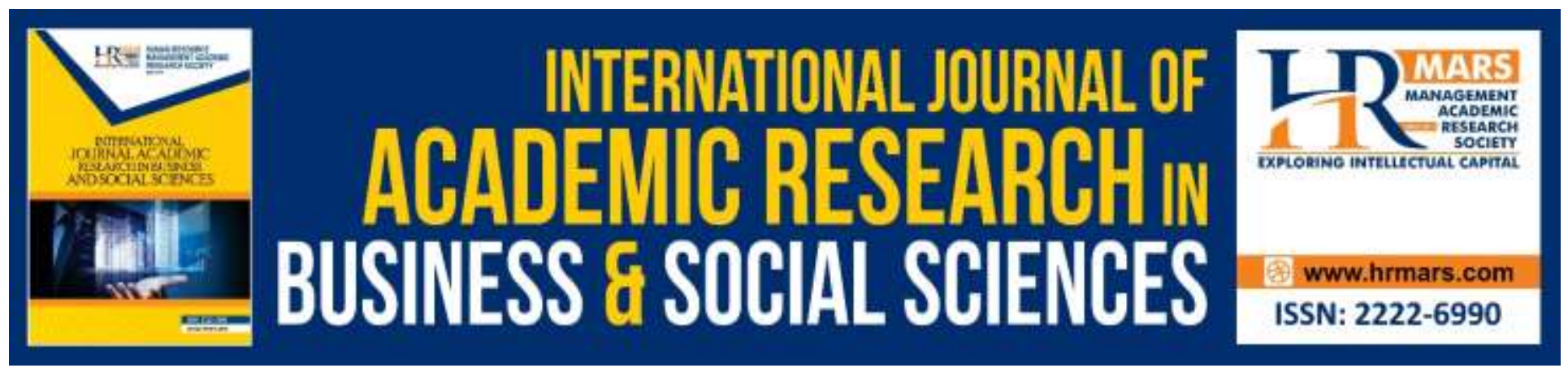

\title{
Determinants of Online Repatronage Intention: A Conceptual Model
}

\section{Ahmad Tamimi Bin Md Som}

To Link this Article: http://dx.doi.org/10.6007/IJARBSS/v10-i3/7068

DOI:10.6007/IJARBSS/v10-i3/7068

Received: 01 February 2020, Revised: 23 February 2020, Accepted: 12 March 2020

Published Online: 04 April 2020

In-Text Citation: (Som, 2020)

To Cite this Article: Som, A. T. B. M. (2020). Determinants of Online Repatronage Intention: A Conceptual Model. International Journal of Academic Research in Business and Social Sciences, 10(3), 521-532.

\section{Copyright: (c) 2020 The Author(s)}

Published by Human Resource Management Academic Research Society (www.hrmars.com)

This article is published under the Creative Commons Attribution (CC BY 4.0) license. Anyone may reproduce, distribute, translate and create derivative works of this article (for both commercial and non-commercial purposes), subject to full attribution to the original publication and authors. The full terms of this license may be seen

at: http://creativecommons.org/licences/by/4.0/legalcode

Vol. 10, No. 3, 2020, Pg. 521 - 532

http://hrmars.com/index.php/pages/detail/IJARBSS

JOURNAL HOMEPAGE

Full Terms \& Conditions of access and use can be found at http://hrmars.com/index.php/pages/detail/publication-ethics 


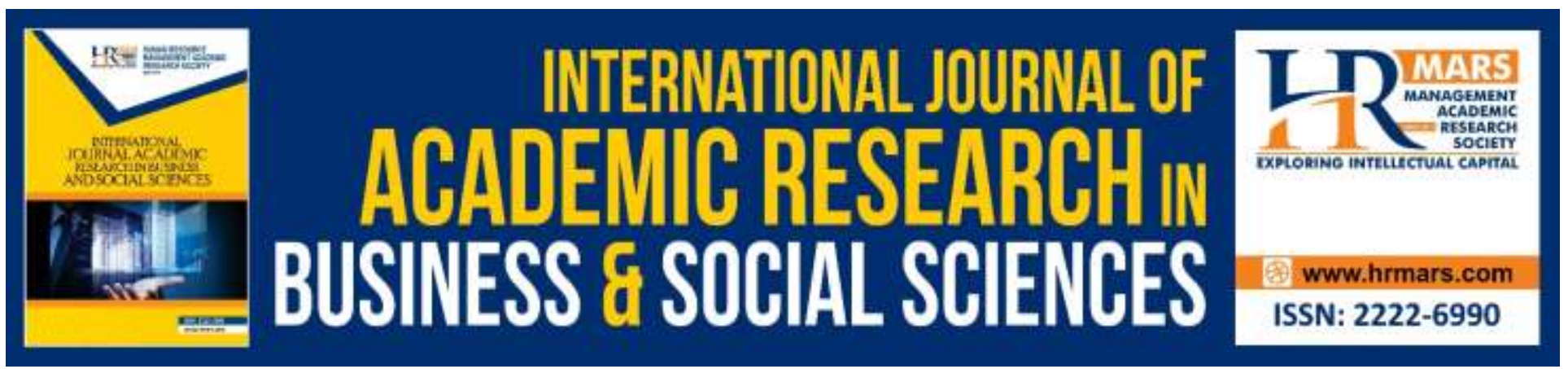

\title{
Determinants of Online Repatronage Intention: A Conceptual Model
}

\author{
Ahmad Tamimi Bin Md Som \\ Politeknik Kota Kinabalu, Sabah, Malaysia
}

\begin{abstract}
As of now, 10 million Malaysian are estimated as active purchasers who conduct transactions through online platform. Similar with physical retailing market, customer retention issue is very crucial to be emphasized by the online retailer to ensure their sustainability in intense and challenging digital economy market. Previous studies on online purchasing behavior mostly focusing on the initial stage of customer's online purchase intention and customer's online continuance or repurchase intention. Nonetheless, the study focusing on online repatronage intention (ORI) still received less attention by the researchers. Thus, this study attempts to develop a conceptual model by integrating the TAM and E-SERVQUAL model to investigate the determinants of ORI. In the proposed model, TAM play a role to determine the influence of online system usage experience towards ORI. Whilst, the adaptation of E-SERVQUAL model is to identify the influence of online system purchase experience towards ORI. Additionally, seven propositions are developed based on the proposed model and reviews of the literature. Finally, conclusions, managerial implications, and future direction of research are also provided.
\end{abstract}

Keywords: Customer Retention, Online System Experience, Online Repatronage Intention (Ori), Tam, E-SERVQUAL.

\section{Introduction}

In today's modern age, according to (Kandulapati \& Bellamkonda, 2014), technology plays a very important role in bridging the gaps that exist between the physical and online purchasing. The online approach channel is the utmost importance to be implemented as a new millennial business model by most retailers. With the growth of online marketplace, entrepreneurs need to shift their focus from finding new customers to motivate existing customers to make purchases using online channel (Chiu et al., 2012). Most researchers and industry practitioners have recognized the importance of maintaining customer buy-in in the online business market (Khalifa \& Liu, 2007; Y. Fang et al., 2014) as efforts to reach new customers require high cost and longer time than maintaining existing customers (Arya \& Srivastava, 2015). 
Consistent purchases from customers reflect the success of an online business (Chou \& Hsu, 2015) and it also means that they have a competitive advantage that will directly increase their sales profit (Rafiq \& Fulford, 2005). Compared to the physical market, keeping customers in the online marketplace is more difficult due to the challenges in the environment itself. Kassim and Abdullah (2008) stated that consumers do not need high costs to change their purchases as it does not involve the cost and physical effort for web options. Easy access to information, the opportunity to compare prices, the level of trust in online business operator as well as negative experiences in previous processes or transactions have also been significant challenges in maintaining customer purchases (Chiu et al., 2009).

The intention to purchase online is also closely related to the experience that individuals have had with online transactions and it directly affects the behavior of individual shopping through this medium (Monsuwé, Dellaert \& Ruyter, 2004). Knowledge of how past experience affects individual buying behavior is also important because there are indeed differences between physical and online purchases (Scarpi, Pizzi \& Visentin, 2014) as well as differences during pre-adoption and postadoption (Rezaei, Amin \& W. Ismail, 2014) that affect individual purchasing behavior. Studies emphasizing the relationship between past purchase experience and future purchase intentions (Weisberg, Te'eni \& Arman, 2011) particularly focusing on online repatronage intention are still lacking.

\section{Literature Review \\ Online Repatronage Intention (ORI)}

Online purchasing activity involves the process of exchanging time, effort and money to obtain a product or service from a virtual shop or online retailer $(\mathrm{Wu}, 2013)$. The online purchase intention is an individual's desire to make a purchase action through an online medium (Chen et al., 2010) or a situation in which consumers intend to buy through the internet medium (Pavlou, 2003). From the perspective of Koppius et al. (2005), he stated that the online repurchase intention refers to the status of a customer who has at least one (1) time made an online purchase and wishes to repeat it. Whereas the online repurchase intention according to Chiu et al. (2012) is likely that experienced customers will continue to use the online medium for their next purchase.

Bhattacherjee (2001) argues that the online continuance intention refers to the customer's intention to continue using the online system in the future. Whereas in the internet trade context, the terms of online repurchase intention is shared the same meaning as the online continuance intention (Mohamed et al., 2014). Jones and Reynolds (2006) further defined repatronage intention as the possibility that shoppers would continue their purchase at the same store or retailer. While according to Reynolds et al. (2012), online repatronage intention is intended as an experienced customer's desire to once again make an online purchase through the same online retailer in the future.

The study of online repatronage intention, online continuance intention, or online repurchase intention seen to be very important because the findings from previous studies has relevance with the issue of customer retention within the context of retail operations. All the defined terms above 
INTERNATIONAL JOURNAL OF ACADEMIC RESEARCH IN BUSINESS AND SOCIAL SCIENCES Vol. 10, No. 3, March, 2020, E-ISSN: 2222-6990 C 2020 HRMARS

are intended to make clear that there are differences among all the terms. Indirectly it will explain that the focus of this study is on the intention to make online repurchases by individuals who are experienced in online purchases and wish to repeat them through the same online retailers in the future or is also known as the online repatronage intention (ORI).

\section{Technology Acceptance Model (TAM)}

There are various models and theories that can be used to study the factors that can influence an individual's attitude and desire for something. However, the Technology Acceptance Model (TAM) introduced by Davis, Bagozzi and Warshaw (1989) which adapted and developed from the Theory of Reasoned Action (TRA) by Fishbein and Ajzen (1975) and the Theory of Planned Behavior (TPB) by Ajzen (1985) is the most influential and widely used model in studies related to electronic commerce or e-commerce (Tong, 2010) and information technology systems (Celik, 2011).

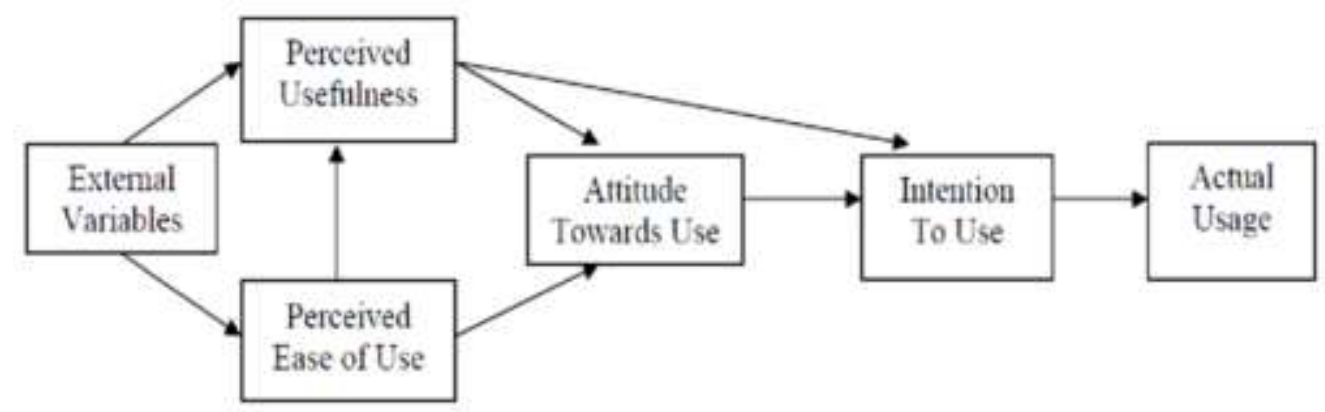

Figure 1: Technology Acceptance Model (Davis et al. 1989)

The TAM model introduced by Davis et al. (1989) as shown in Figure 1, is a theory used to determine how consumers respond to and adopts new technologies. This model states that when a user is exposed to the use of a new technology, there are 2 main constructs that will influence their behavior and their decision to use it which is perceived usefulness and perceived ease of use. Both constructs are an important factor in determining consumer attitudes and satisfaction with online purchases and are widely used in studies related to online business markets (Celik, 2011).

Perceived usefulness refers to consumers' perception of the benefits derived from the experience of using a technology while perceived ease of use refers to their perception of the process of using a technology that leads to the benefits derived from it (Mansori, Liat \& Shan, 2012). In short, the TAM model states that the intention to use a new technology is determined by the attitude of the user itself during and after the process of using the technology.

Based on the discussion of the TAM model in previous studies (Chen, Gillenson \& Sherrell, 2002; Lee, Fiore \& Kim, 2006; Ha \& Stoel, 2009), it is proven that this model is very relevant to serve as a strong theoretical basis for conducting studies to identify consumer acceptance and response to the use of new technologies in online purchasing activities. While according to Wen, Prybutok and $\mathrm{Xu}$ (2011), the TAM model is a strong indicator of utilitarian factors in studying intentions for online repurchase. Therefore, as this study focuses on the online marketplace, innovations in the transaction 
INTERNATIONAL JOURNAL OF ACADEMIC RESEARCH IN BUSINESS AND SOCIAL SCIENCES Vol. 10, No. 3, March, 2020, E-ISSN: 2222-6990 C 2020 HRMARS

system as well as the method of selling and buying goods and consumer attitudes towards online purchases, the TAM model will be used as the basis of this research framework.

\section{E-SERVQUAL Model}

Service quality according to Parasuraman, Zeithaml and Berry (1988) is the difference between customer expectations and the actual level of service performance of a firm. While e-service quality involves the entire phase of the interaction between the customer and the website, which includes the level of efficiency and effectiveness of the website in facilitating the purchase and delivery process (Parasuraman, Zeithaml \& Malhotra, 2005). Parasuraman et al. (1988) developed an instrument called SERVQUAL that has 5 main dimensions namely reliability, responsiveness, empathy, assurance and tangibility to measure customer perception or response to service quality received.

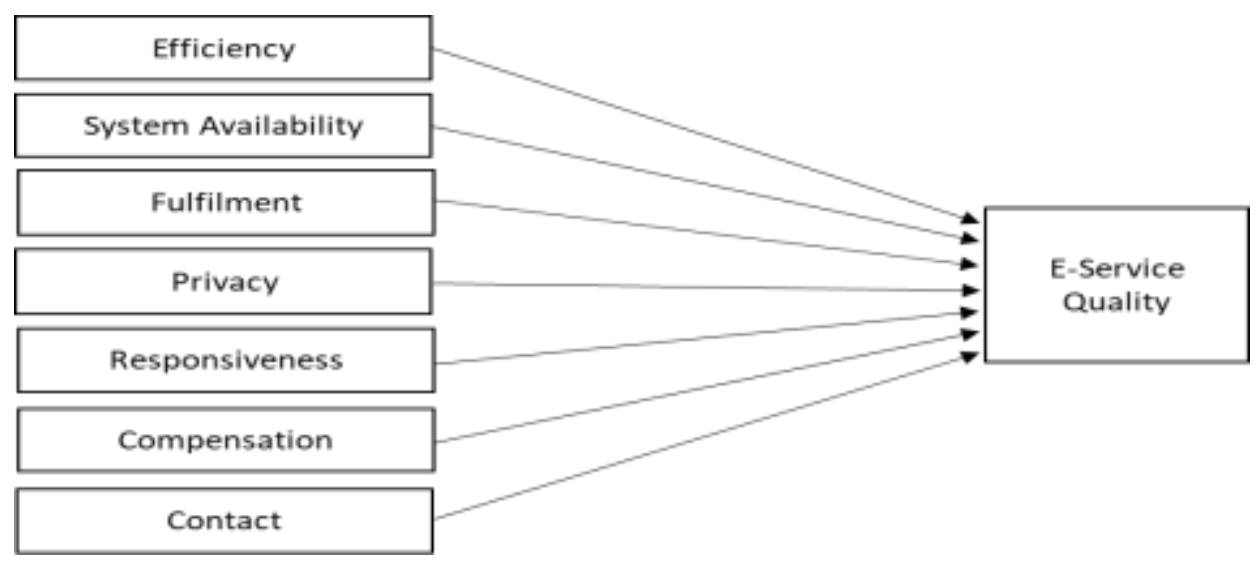

Figure 2: E-SERVQUAL Model (Parasuraman et al. 2005)

With the increasing acceptance and confidence that measurement of service quality in an ecommerce market environment is different from measurement in physical market environment, most online marketplace studies have now used e-service quality or E-SERVQUAL measurement methods developed by Parasuraman et al. (2005) as shown in Figure 2. The E-SERVQUAL model has seven (7) dimensions: efficiency, system availability, fulfillment, privacy, responsiveness, compensation and contact. Y.-H. Fang et al. (2011) explained that due to the uniqueness inherent in the e-commerce market, the E-SERVQUAL measurement method should be adapted to the use of the instruments contained in SERVQUAL.

\section{Development of Research Framework and Hypothesis}

Based on the discussions and reviews of the literature, this study will integrate the use of TAM and E-SERVQUAL models as conceptual models to identify factors that influence online repatronage intention. The framework and hypothesis of the study as shown in Figure 3 are the model suggestions for this study. The dependent variable, which is online repatronage intention (ORI), is the main construct for determining consumer purchasing behavior, which refers to the likelihood of customers making a purchase with the same online retailer in the future. 
INTERNATIONAL JOURNAL OF ACADEMIC RESEARCH IN BUSINESS AND SOCIAL SCIENCES Vol. 10, No. 3, March, 2020, E-ISSN: 2222-6990 @ 2020 HRMARS

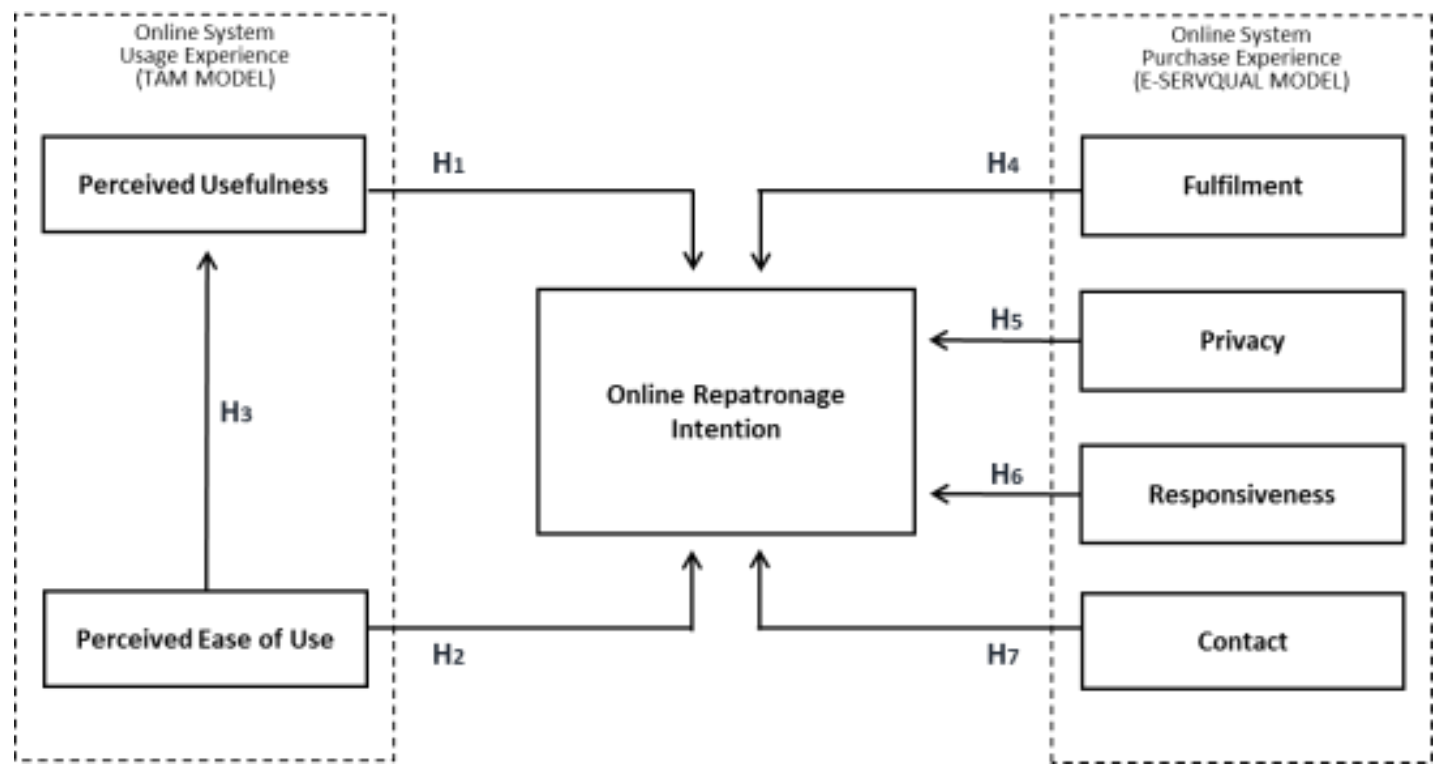

Figure 3: Conceptual Research Framework

Two (2) predictor variables in the TAM model namely perceived usefulness and perceived ease of use are factors that explain the effect of experience in using an online system towards ORI. While the dimensions representing the E-SERVQUAL model consisting of variables of fulfillment, privacy, responsiveness and contact were adapted to study the impact of the online purchasing experience on ORI. Practically in this study, the TAM model was adapted due to its significant influence on the intention to take specific action related to the use of new technologies or information systems. Monsuwé et al. (2004) explained that perceived usefulness is how internet effectively helping purchase activities and the perceived ease of use is how easy to use internet as a medium for making purchases. Previous studies have also shown that these two factors are positively related (Chiu et al., 2009; Al-Maghrabi \& Dennis, 2011; Wen et al., 2011) and may influence the intention to make a purchase in the future (Lee, Eze \& Ndubisi, 2011).

While, the dimensions of E-SERVQUAL is an important component of measuring the success of an online business. Success is also measured by the level of customer satisfaction that drives them to return to the same service provider in the future (Parasuraman et al., 2005). However, for the purpose of this study, only four (4) dimensions were adapted from the E-SERVQUAL model which is fulfillment, privacy, responsiveness, and contact. It is due to the reason that the perceived usefulness and perceived ease of use in the TAM model will explain the elements of efficiency and system availability in the E-SERVQUAL model. Whereas for the compensation dimension, it is not adapted due to the low number of experienced customers receiving compensation for service failure (Chiu et al., 2009) and it is only important to adapt for things that are irregular (Parasuraman et al., 2005). All of the relationships between these variables can be identified through the conceptual frameworks and hypotheses of the research developed. 
INTERNATIONAL JOURNAL OF ACADEMIC RESEARCH IN BUSINESS AND SOCIAL SCIENCES

Vol. 10, No. 3, March, 2020, E-ISSN: 2222-6990 @ 2020 HRMARS

\section{Perceived Usefulness}

Perceived usefulness is an important aspect of the buying process as consumers often make judgments and based on the information gained before making a decision to purchase (Babin, Darden \& Griffin, 1994). Referring to the TAM model by Davis (1989), perceived usefulness has a weak relationship with attitude but has a very strong relationship to intention. He explained that the intention to use a new technology arises from the benefits gained. Therefore, this research proposes the following hypotheses:

\section{H1: Perceived usefulness has significant influence on online repatronage intention.}

\section{Perceived Ease of Use}

Referring to the TAM model, perceived ease of use is often highly influential in the early stages of the user experience to a new technology or information system introduced (Davis, 1989). In other words, if a user finds that a system (website) is difficult to operate, fails to find the product they want or is not clear with the offer, they will usually leave the site (Pearson, Pearson \& Green, 2007). Vice versa, when a system becomes easier to use, the consumer's determination to use is increased (Monsuwé et al., 2004) and this may influence their intention to make future purchases (C. H. Lee et al., 2011). The following hypotheses is thus proposed:

\section{H2: Perceived ease of use has significant influence on online repatronage intention.}

With the increasing number of users exposed to internet technology, King and He (2006) emphasized that perceived ease of use is an important aspect to consider in the system development. This is because this factor has a positive relationship with the intention to make an online purchase (Ramayah \& Ignatius, 2005) and has a direct relationship to perceived usefulness in the context of online purchase (Wen et al., 2011). The hypotheses are then proposed:

H3: User's perceived ease of use in using the system has significant influence on their perceived usefulness of the system.

\section{Fulfillment}

When a customer deals with an online seller, it is indirectly creating a psychological contract that the seller will fulfill their promise and responsibility (Chiu et al., 2009) and failure to comply will cause distrust (Robinson \& Rousseau, 1994). According to Parasuraman et al. (2005), several previous studies have shown that this factor of fulfillment is the strongest indicator of customer satisfaction and service quality as well as some of the strong indicators that influence intention to make a purchase through a website. Thus, the following hypothesis is proposed:

H1: Fulfilment has significant influence on online repatronage intention.

\section{Privacy}

According to Chiu et al. (2009), the privacy term refers to the degree of security of a website and how it protects the personal information of the customer. Most consumers who have not yet 
INTERNATIONAL JOURNAL OF ACADEMIC RESEARCH IN BUSINESS AND SOCIAL SCIENCES

Vol. 10, No. 3, March, 2020, E-ISSN: 2222-6990 @ 2020 HRMARS

made an online purchase are out of desperation, where they feel their personal information will be disclosed to a third party without their prior permission. Similarly, according to Collier and Bienstock (2006), consumers will reject the use of online mediums for shopping if they feel insecure such as their credit card information is safe from hacker threats. According to Rezvani and Safahani (2016), the security of the online transaction system and its ability to safeguard customer privacy information is crucial to increasing online purchases. The following hypothesis is therefore proposed:

\section{H1: Privacy has significant influence on online repatronage intention.}

\section{Responsiveness}

According to Yang, Jun and Peterson (2004), responsiveness is one of the most important factors in determining the level of e-quality of service. During the process of interacting with online retailers, it is important for customers to get a prompt and efficient response if they encounter any problems (Semeijn et al., 2005). Whereas Chiu et al. (2009) stated that customers see responsiveness as the ability of the seller to address any possible service failure. Proactive measures to address this need to be designed to avoid losing customers' trust, and their failure to do so will certainly have an impact on future customer buying behavior (Collier \& Bienstock, 2006). Thus, this research provides the following hypotheses:

\section{H1: Responsiveness has significant influence on online repatronage intention.}

\section{Contact}

Providing a variety of methods to enable customers to connect with sellers is critical to improving their perception of the quality of their services and operations online (Collier \& Bienstock, 2006). According to Chiu et al. (2009), online customers can easily become frustrated if they fail to contact a customer service representative for help or to answer a question. Parasuraman et al. (2005) stated that online firms may be able to provide good e-services even with little or no involvement of people. However, Chiu et al. (2009) explain that, in the context of service recovery, engagement among people is particularly needed to provide feedback, answer any questions and take follow-up actions. Therefore, the proposed hypothesis is:

\section{H1: Contact has significant influence on online repatronage intention.}

\section{Future Research Directions and Limitations}

The aim of this study was to develop a conceptual framework for the study to identify factors influencing online repatronage intention. The development of the conceptual model of this study took into two (2) different models, TAM and E-SERVQUAL as the basis for its development. The integration between the two models will be used to analyze the influence of factors such as perceived usefulness, perceived ease of use, fulfillment, privacy, responsiveness and contact with online repatronage intention. As the physical retail environment, the assessment of the critical success factor of online retailers can also be measured by the purchase of existing customers. Although the presence of new customers is also important to firms, efforts to attract them will cost significantly more than retaining existing customers (Arya \& Srivastava, 2015). Therefore, the focus of this study 
INTERNATIONAL JOURNAL OF ACADEMIC RESEARCH IN BUSINESS AND SOCIAL SCIENCES Vol. 10, No. 3, March, 2020, E-ISSN: 2222-6990 @ 2020 HRMARS

is directed at a group of experienced users making online purchases through online retailers in virtual merchant categories such as Lazada.com.my, 11th Street.com.my, Shopee.com.my and other retailers in the same category in Malaysia. The focus to this group of users is seen to be in line with the objectives of this study which is to identify the influence of user experience factors on online repatronage intention. It could contribute a valuable data and information to the online retailers to become a based in the development of customer retention strategy. However, there are still some barriers or limitations to the study that need to be taken into consideration during the implementation of this study.

(1) This research model is only aimed at virtual merchant such as Lazada.com.my, 11th Street.com.my, Shopee.com.my and etc. However, to apply the same model for other online retail or business category, it can be the focus to be explored by the future researcher.

(2) In the aspect of research, several factors can influence the user's online repatronage intention. However, this research is only focusing on the aspects of online system usage and online system purchase experience. To have clearer understanding towards the issue, more studies are needed in the future to explore the other contributing factors.

(3) The subjects for this research are experienced online shoppers in Malaysia. However, in different countries we realized that there are clear differences in their online market development, culture, buying preferences and etc. Hence, this research application and results might not suitable for other countries.

\section{Acknowledgement}

Many thanks and appreciation to Associate Professor Dr. Maisarah binti Ahmad for all the guidance and expertise contributed throughout the course of this study. The Graduate School of Business, National University of Malaysia (UKM-GSB), the Ministry of Education Malaysia (Department of Polytechnic and Community College, Scholarship Division, Human Resource Division) who has opened up a lot of chance and financial opportunities in realizing my desire to do this research.

\section{Corresponding Author}

Associate Professor Dr. Maisarah Binti Ahmad, Universiti Teknologi Petronas (UTP), Malaysia, Email: maisarah.ahmad@utp.edu.my

\section{References}

Ajzen, I. (1985). From Intentions to Actions: A Theory of Planned Behavior. Action Control: From Cognition to Behavior, (C) Springer, 11-39.

Ajzen, I. (1991). The Theory of Planned Behavior. Orgnizational Behavior and Human Decision Processes, 50, 179-211.

Al-Maghrabi, T., \& Dennis, C. (2011). What Drives Consumers'Continuance Intention to E-Shopping? Conceptual Framework and Managerial Implications in the Case of Saudi Arabia. International Journal of Retail \& Distribution Management, 39(12), 899-926.

Arya, S., \& Srivastava, S. (2015). Effects of User's Primary Need on Relationship Between E-Loyalty 
INTERNATIONAL JOURNAL OF ACADEMIC RESEARCH IN BUSINESS AND SOCIAL SCIENCES

Vol. 10, No. 3, March, 2020, E-ISSN: 2222-6990 @ 2020 HRMARS

and its Antecedents. Decision, 42(4), 419-449.

Babin, B. J., Darden, W. R., \& Griffin, M. (1994). Work and/or Fun: Measuring Hedonic and Utilitarian Shopping Value. Journal of Consumer Research, 20(4), 644-657.

Bhattacherjee, A. (2001). An Empirical Analysis of the Antecedents of Electronic Commerce Service Continuance. Decision Support Systems, 32(2), 201-214.

Celik, H. (2011). Influence of Social Norms, Perceived Playfulness and Online Shopping Anxiety on Customers' Adoption of Online Retail Shopping: An Empirical Study in the Turkish Context. International Journal of Retail \& Distribution Management, 39(6), 390-413.

Chen, L., Gillenson, M. L., \& Sherrell, D. L. (2002). Enticing Online Consumers: An Extended Technology Acceptance Perspective. Information and Management, 39(8), 705-719.

Chen, Y.-H., Hsu, I.-C., \& Lin, C.-C. (2010). Website Attributes That Increase Consumer Purchase Intention: A Conjoint Analysis. Journal of Business Research, 63(9-10), 1007-1014.

Chiu, C.-M., Chang, C.-C., Cheng, H.-L., \& Fang, Y.-H. (2009). Determinants of Customer Repurchase Intention in Online Shopping. Online Information Review, Vol. 33, pp. 761-784.

Chiu, C.-M., Wang, E., Fang, Y., \& Huang, H. (2012). Understanding Customers' Repeat Purchase Intentions in B2C e-Commerce: The Roles of Utilitarian Value, Hedonic Value and Perceived Risk. Information Systems and E-Business Management, 24, 85-114.

Chou, S.-W., \& Hsu, C.-S. (2015). Understanding Online Repurchase Intention: Social Exchange Theory and Shopping Habit. Information Systems and E-Business Management.

Collier, J. E., \& Bienstock, C. C. (2006). Measuring Service Quality in E-Retailing. Journal of Service Research : JSR, 8(3), 260.

Davis, F. D. (1989). Perceived Ease of Use, and User Acceptance of Information Technology. MIS Quarterly, 13(3), 319-340.

Davis, F. D., Bagozzi, R. P., \& Warshaw, P. R. (1989). User Acceptance of Computer Technology : A Comparison of Two Theoretical Models. Management Science, 35(8), 982-1003.

Fang, Y.-H., Chiu, C. M., \& Wang, E. T. G. (2011). Understanding Customers' Satisfaction and Repurchase Intentions. Internet Research, 21(4), 479-503.

Fang, Y., Qureshi, I., Sun, H., McCole, P., Ramsey, E., \& Lim, K. H. (2014). Trust, Satisfaction and Online Repurchase Intention: The Moderating Role of Perceived Effectiveness of E-Commerce Institutional Mechanism. MIS Quarterly, 38(2), 407-427.

Ha, S., \& Stoel, L. (2009). Consumer e-Shopping Acceptance: Antecedents in a Technology Acceptance Model. Journal of Business Research, 62(5), 565-571.

Jones, M. A., \& Reynolds, K. E. (2006). The Role of Retailer Interest on Shopping Behavior. Journal of Retailing, 82(2), 115-126.

Kandulapati, S., \& Bellamkonda, R. S. (2014). E-Service Quality: A Study of Online Shoppers in India. American Journal of Business, 29(2), 178-188.

Kassim, N. M., \& Abdullah, N. A. (2008). Customer Loyalty in E-commerce Settings: An Empirical Study. European Journal of Marketing, 18(3), 275-290.

Khalifa, M., \& Liu, V. (2007). Online Consumer Retention: Contingent Effects of Online Shopping Habit and Online Shopping Experience. European Journal of Information Systems, 16(August 2005), 780-792.

King, W. R., \& He, J. (2006). A Meta-Analysis of the Technology Acceptance Model. Information and Management, 43(6), 740-755. 
INTERNATIONAL JOURNAL OF ACADEMIC RESEARCH IN BUSINESS AND SOCIAL SCIENCES

Vol. 10, No. 3, March, 2020, E-ISSN: 2222-6990 @ 2020 HRMARS

Koppius, O., Speelman, W., Stulp, O., Verhoef, B., \& van Heck, E. (2005). Why are Customers Coming Back to Buy Their Airline Tickets Online? Theoretical Explanations and Empirical Evidence. Proceedings of the 7th International Conference on Electronic Commerce - ICEC '05, 319.

Lau, S. H., \& Woods, P. C. (2009). Understanding the Behavior Changes in Belief and Attitude Among Experienced and Inexperienced Learning Object Users. Computers and Education, 52(2), 333342.

Lee, C. H., Eze, U. C., \& Ndubisi, N. O. (2011). Analyzing Key Determinants of Online Repurchase Intentions. Asia Pacific Journal of Marketing and Logistics, 23(2), 200-221.

Lee, H.-H., Fiore, A. M., \& Kim, J. (2006). The role of the Technology Acceptance Model in Explaining Effects of Image Interactivity Technology on Consumer Responses. International Journal of Retail \& Distribution Management, 34(8), 621-644.

Lin, C., \& Lekhawipat, W. (2014). Factors Affecting Online Repurchase Intention. Industrial Management \& Data Systems, 114(4), 597-611.

Mansori, S., Liat, C. B., \& Shan, L. H. (2012). A Study of E-Shopping Intention In Malaysia: The Influence Of Generation X \& Y. Australian Journal of Basic and Applied Sciences, 6(8), 28-35.

Mohamed, N., Hussein, R., A. Zamzuri, N. H., \& Haghshenas, H. (2014). Insights into Individual's Online Shopping Continuance Intention. Industrial Management \& Data Systems, 114(2), 1453-1476.

Monsuwé, T. P. Y., Dellaert, B. G. C., \& Ruyter, K. De. (2004). What Drives Consumers to Shop Online? A Literature Review. International Journal of Service Industry Management, 15(1), 102-121.

Parasuraman, A., Zeithaml, V. A., \& Berry, L. L. (1988). ServquaSERVQUAL. A Multiple-Item Scale for Measuring Consumer Perceptions of Service Quality. Jorunal of Retailing, 64, 12-40.

Parasuraman, A., Zeithaml, V. A., \& Malhotra, A. (2005). E-S-QUAL: A Multiple-Item Scale for Assessing Electronic Service Quality. Journal of Service Research, 7(Feb.), 1-21.

Pavlou, P. A. (2003). Consumer Acceptance of Electronic Commerce: Integrating Trust and Risk with the Technology Acceptance Model. International Journal of Electronic Commerce, 7(3), 69-103.

Pearson, J. M., Pearson, A., \& Green, D. (2007). Determining the Importance of Key Criteria in Web Usability. Management Research News, 30(11), 816-828.

Rafiq, M., \& Fulford, H. (2005). Loyalty Transfer From Offline to Online Stores in the UK Grocery Industry. International Journal of Retail \& Distribution Management, 33(6), 444-460.

Ramayah, T., \& Ignatius, J. (2005). Impact of Perceived Usefulness, Perceived Ease of Use and Perceived Enjoyment on Intention to Shop Online. IFCAI Journal of System Management, 3(3), 36-51.

Reynolds, K. E., Jones, M. A., Musgrove, C. F., \& Gillison, S. T. (2012). An Investigation of Retail Outcomes Comparing Two Types of Browsers. Journal of Business Research, 65(8), 1090-1095.

Rezaei, S., Amin, M., \& W. Ismail, W. K. (2014). Online Repatronage Intention: An Empirical Study Among Malaysian Experienced Online Shoppers. International Journal of Retail \& Distribution Management, 42(5), 390-421.

Rezvani, M., \& Safahani, N. (2016). The Effect of Site Quality on Electronic Word of Mouth Marketing Through Mediating Variable of Customer Satisfaction (Case Study: Tiwall Culture and Art Social Network Online Shop). International Business Management, Vol. 10, pp. 592-598.

Robinson, S. L., \& Rousseau, D. M. (1994). Violating the Psychological Contract: Not the Exception but the Norm. Journal of Organizational Behavior, 15(3), 245-259.

Scarpi, D., Pizzi, G., \& Visentin, M. (2014). Shopping for Fun or Shopping to Buy: Is it Different Online 
INTERNATIONAL JOURNAL OF ACADEMIC RESEARCH IN BUSINESS AND SOCIAL SCIENCES

Vol. 10, No. 3, March, 2020, E-ISSN: 2222-6990 @ 2020 HRMARS

and Offline? Journal of Retailing and Consumer Services, 21(3), 258-267.

Semeijn, J., Riel, A. C. R. van, Birgelen, M. J. H. van, \& Streukens, S. (2005). E-Services and Offline Fulfilment: How E-Loyalty is Created. Managing Service Quality, 15(2), 182-194.

Tong, X. (2010). A Cross-national Investigation of an Extended Technology Acceptance Model in the Online Shopping Context. International Journal of Retail \& Distribution Management, 38(10), 742-759.

Weisberg, J., Te'eni, D., \& Arman, L. (2011). Past Purchase and Intention to Purchase in E-commerce: The Mediation of Social Presence and Trust. Internet Research, 21(1), 82-96.

Wen, C., Prybutok, V. R., \& Xu, C. (2011). An Integrated Model for Customer Online Repurchase Intention. Journal of Computer Information Systems, 14(Fall 2011), 14-23.

Wu, I. L. (2013). The Antecedents of Customer Satisfaction and its Link to Complaint Intentions in Online Shopping: An Integration of Justice, Technology, and Trust. International Journal of Information Management, 33(1), 166-176.

Yang, Z., Jun, M., \& Peterson, R. T. (2004). Measuring Customer Perceived Online Service Quality: Scale Development and Managerial Implications. International Journal of Operations \& Production Management, 24(11), 1149-1174.

Yi, Y., \& La, S. (2004). What Influences the Relationship between Customer Satisfaction and Repurchase Intention? Investigating the Effects of Adjusted Expectations and Customer Loyalty. Psychology and Marketing, 21(5), 351-373. 